\title{
$P-26$
}

\section{高尿酸血症の病型別に見たフェブキソスタット及び トピロキソスタットの尿酸降下作用}

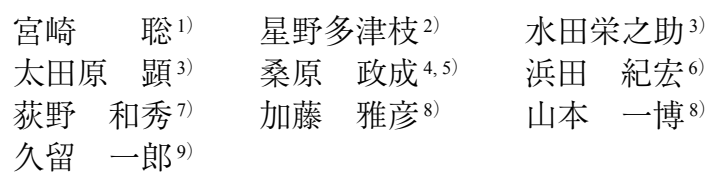

\section{背景・目的}

高尿酸血症は血清尿酸值 (SUA) が $7.0 \mathrm{mg} / \mathrm{dL}$ を 超えた状態と定義され，高血圧発症の独立した予 測因子，心不全の予後予測因子でありまた最近で は心血管疾患のリスク因子とする報告が増加して おり高血圧患者や循環疾患患者での血清尿酸值の 管理は今後重要なテーマになると思われる。高尿 酸血症・痛風の治療ガイドライン (第 2 版) からは 病型分類により尿酸排泄促進薬と尿酸産生抑制 薬を使い分けることが推奨されている。しかし 2002年に行われた千葉県尿酸談話会の調査では 4 分の 3 の医師が病型分類を必ずしも実施せずに治 療を行っており, 薬剤選択では $2 / 3$ 医師は尿酸産 生抑制薬を投与していた。新規尿酸コントロー ル薬フェブキソスタット $(\mathrm{Feb})$ 及びトピロキソス タット（Top）はキサンチンオキシダーゼを選択的 に阻害し尿酸産生を抑制し尿酸低下作用を発揮す る。これらの薬剤の排泄経路からアロプリノール と異なり腎障害患者にも用量調節なく使用し易 い薬剤でありFortune2 研究からはFebは産生過剩 (OP) のみならず排泄低下 $(\mathrm{UE})$ 患者にも同等に 尿酸を低下させる報告されている.

実臨床での Feb及びTopの使用実態及びその効
果を明らかにするため協力医療機関での患者デー タの検討を行った。

\section{方 法}

外来通院中の高尿酸血症患者で Feb及び Top 投 与前後のSUA，尿中尿酸排泄，腎機能，血圧及 び脈拍などを病型別・用量別に検討を行った。

\section{結 果}

Feb 群は 90 例, 平均用量 $18 \mathrm{mg}$ で $8.5 \mathrm{mg} / \mathrm{dL} \rightarrow$ $6.1 \mathrm{mg} / \mathrm{dL}(\mathrm{p}<0.001)$ と有意に低下し $\mathrm{SUA} 6 \mathrm{mg} / \mathrm{dL}$ 以下達成率は $51 \%$ であった。用量別では $10 \mathrm{mg}$ 群 $1.9 \mathrm{mg} / \mathrm{dL}(20 \%), 20 \mathrm{mg}$ 群 $2.4 \mathrm{mg} / \mathrm{dL}(27 \%), 40 \mathrm{mg}$ 群 $4.0 \mathrm{mg} / \mathrm{dL}$ (44\%) と用量依存性を認めた.

病型別では $\mathrm{OP}$ 群 17 例の平均用量は $22 \mathrm{mg}$ で $3.6 \mathrm{mg} / \mathrm{dL}(37 \%)$ 低下し, UE群 44例の平均用量は $19 \mathrm{mg}$ で $2.7 \mathrm{mg} / \mathrm{dL}(29 \%)$ 低下した. OP群とUE群 間の変化量・変化率には有意差はなかったが $\mathrm{OP}$ 群で血清尿酸值低下効果は高い傾向であった.

Top 群は 22 例, 平均用量 $63 \mathrm{mg}$ で $8.0 \mathrm{mg} \rightarrow 6.3 \mathrm{mg} /$ $\mathrm{dL}(\mathrm{p}<0.01)$ と有意に低下し SUA6mg/dL 以下達 成率は $50 \%$ であった. 用量別では $40 \mathrm{mg}$ 群は $1.6 \mathrm{mg} /$ dL (19\%)， 80mg 群は $2.5 \mathrm{mg} / \mathrm{dL}$ (34\%)，120mg 群
1) 仁厚会藤井政雄記念病院循環器内科

2）ほしの内科・胃腸科クリニック

3 ) 山陰労災病院循環器科

4 ) University of Colorado Denver, School of Medicine

5 ）虎の門病院 循環器センター内科

6) 鳥取大学医学部地域医療学

7 ) 鳥取大学医学部臨床検査学

8）鳥取大学医学部病態情報内科学

9) 鳥取大学大学院医学系研究科再生医療学分野

\section{Satoshi Miyazaki}

Tazue Hoshino

Einosuke Mizuta, Akira Ohtahara

Masanari Kuwabara

Masanari Kuwabara

Toshihiro Hamada

Kazuhide Ogino

Masahiko Kato, Kazuhiro Yamamoto

Ichiro Hisatome 
は $0.7 \mathrm{mg} / \mathrm{dL}(9 \%)$ と低下したが用量依存性はな かった，病型別では OP 群 7例の平均投与量 $60 \mathrm{mg}$ で $2.0 \mathrm{mg} / \mathrm{dL}(25 \%)$ 低下し, UE 群 15 例の平均投 与量 $64 \mathrm{mg}$ で $1.6 \mathrm{mg} / \mathrm{dL}(20 \%)$ 低下した. Feb と同 様に OP群とUE群間の変化量・変化率には有意 差はなかったが $\mathrm{OP}$ 群で血清尿酸值低下効果は高 い傾向であった。

Feb及びTopの投与前後で血圧・脈拍・腎機能 に有意差は認めなかった。

尿酸変化率と血圧変化率の検討を行ったところ $\mathrm{Feb}$ 群で尿酸変化率と収縮期血圧低下率に有意な 相関を認めた $(\mathrm{R}=0.25, \mathrm{p}=0019)$.

\section{考察}

$\mathrm{SUA} 6 \mathrm{mg} / \mathrm{dL}$ 以下達成率は約半数であり, その 原因としては推奨維持投与量までの患者が少ない ことが考えられた。ささらなる尿酸低下を目指すた めには投与量を増加または尿酸排泄薬の併用のい ずれかの選択は検討が必要である。

Feb およびTopは産生過剩型を排泄低下型のシ フトさせ投与後に腎での尿酸排泄低下を招くため に尿酸低下効果を減弱させる要因となる可能性が ある。

Febでは尿酸低下率と収縮期血圧低下率には優 位な相関を認め血管内皮機能改善などの機序が考 えられる。

\section{結 語}

Feb 及びTop は病型に依存しない尿酸低下作用 を示す。今後新規産生抑制薬 Feb及びTopを使用 する際の病型分類の必要性についての検討が必要 と思われる。 